\title{
ADSORPSI ZAT WARNA CONGO RED MENGGUNAKAN KITOSAN-MMT DENGAN METODE FIXED-BED COLUMN
}

Rena Purnama Sari ${ }^{1}$ Erdawati $^{1}$, dan Imam Santoso ${ }^{1}$

${ }^{1}$ Jurusan Kimia, Fakultas Matematika Ilmu Pengetahuan Alam Universitas Negeri Jakarta, Jl. Pemuda No.10, Rawamangun, Jakarta, Indonesia

\begin{abstract}
Abstrak
Penelitian ini bertujuan untuk mengetahui kemampuan kitosan yang dimodifikasi dengan monmorillonit dalam mengadsorpsi zat warna congo red menggunakan metode fixed-bed column. Kitosan-MMT dikarakterisasi dengan FTIR, XRD, SAA, dan FESEM. Hasil karakterisasi FTIR menunjukkan adanya serapan untuk gugus $\mathrm{Si}-\mathrm{O}, \mathrm{Al}-\mathrm{O}$, dan amina yang mencirikan monmorillonit dan kitosan. Analisis XRD menghasilkan adanya peningkatan jarak basal dari $12,46 \AA$ untuk monmorillonit menjadi $17,04 \AA$ untuk kitosan-MMT. Luas permukaan kitosan-MMT sebesar $12,882 \mathrm{~m}^{2} / \mathrm{g}$ diketahui melalui analisis SAA. Sedangkan analisis FESEM memperlihatkan morfologi kitosan-MMT dengan diameter pori berkisar antara $152,5 \mathrm{~nm}$ sampai $380,3 \mathrm{~nm}$. Dari proses adsorpsi didapatkan bahwa laju alir adsorbat sebesar 0,2 mL/menit dan berat adsorben 0,5 gram memiliki nilai $\mathrm{q}_{\mathrm{b}}$ terbesar yaitu 25,92 mg/g. Model kinetika Thomas digunakan untuk memprediksi kurva breakthrough. Diperoleh model adsorpsi Thomas sesuai untuk kondisi berat adsorben 0,3 gram dengan laju alir $0,2 \mathrm{~mL} /$ menit dan kondisi laju alir $0,6 \mathrm{~mL} / \mathrm{menit}$ dengan berat adsorben 0,5 gram.
\end{abstract}

Kata kunci adsorpsi, congo red, kitosan, model Thomas, monmorillonit, kurva breakthrough.

\begin{abstract}
This research aim to know the ability of chitosan modified by montmorillonite to adsorp congo red using fixedbed column method. Chitosan-MMT was identified with FTIR, XRD, SAA, and FESEM. FTIR characterization indicate the presence of absorption for sites Si-O, Al-O, and amines that characterizes montmorillonite and chitosan. XRD analysis resulted an increase the basal spacing from $12.46 \AA$ for montmorillonite to $17.04 \AA$ for chitosan-MMT. The surface area of chitosan-MMT is $12.882 \mathrm{~m}^{2} / \mathrm{g}$, known through the analysis of SAA. While the analysis of FESEM shows morphology of chitosan-MMT with pore diameters ranging from $152,5 \mathrm{~nm}$ to $380,3 \mathrm{~nm}$. From the adsorption process was found that the flow rate of the adsorbate at 0,2 $\mathrm{mL} / \mathrm{min}$ and weighs 0,5 grams adsorbent has the greatest $q_{b}$ value is $25.92 \mathrm{mg} / \mathrm{g}$. Thomas kinetic model is used to predict the breakthrough curves. Thomas adsorption model is obtained according to the condition of the adsorbent weight 0,3 grams with a flow rate of $0,2 \mathrm{~mL} / \mathrm{min}$ flow rate and the condition of $0,6 \mathrm{~mL} / \mathrm{min}$ with a weight of 0,5 grams adsorbent.
\end{abstract}

Keywords adsorption, congo red, chitosan, Thomas model, montmorillonite, breakthrough curve.

\section{Pendahuluan}

Perkembangan industri tekstil di Indonesia terus berkembang baik dalam skala besar maupun skala rumah tangga. Perkembangan industri ini dapat dilihat dari nilai ekspor tekstil dan produk tekstil (TPT) yang terus meningkat. Terlepas dari peranannya sebagai komoditi ekspor yang cukup diandalkan, ternyata industri tekstil ini menimbulkan masalah serius bagi lingkungan yang diakibatkan oleh limbar cair yang dihasilkan. Industri tekstil menghasilkan air limbah dengan parameter BOD, COD, padatan tersuspensi, dan warna yang relatif pekat. Umumnya tujuan pengolahan limbah cair industri tekstil adalah mengurangi tingkat polutan organik, logam berat, padatan tersuspensi, dan warna sebelum dibuang ke perairan. Namun, pada saat ini tingkat polutan di Indonesia tidak memasukkan warna sebagai parameter yang diatur. Walaupun demikian, limbah yang mengandung warna sering kali menimbulkan kesulitan dalam kehidupan biota perairan, penggunaan material selanjutnya, serta dalam masalah estetika.

Dalam proses pewarnaan suatu kain pada industri tekstil, sebagian besar produsen tekstil lebih memilih zat warna sintetik. Hal ini disebabkan zat warna sintetik lebih murah, penggunaannya lebih praktis, tidak mudah luntur, dan warnanya lebih bervariasi dari pada zat warna alam. Sekitar 60 hingga $70 \%$ 
zat warna yang digunakan dalam pencelupan tekstil adalah zat warna sintetik golongan azo dan turunannya [1].

Beberapa penelitian penghilangan warna dan senyawa organik yang ada dalam limbah cair industri tekstil telah banyak dilakukan, misalnya dengan proses biologi untuk mereduksi senyawa organik dari limbah cair industri tekstil. Namun, efisiensi penghilangan warna melalui proses biologi ini sering kali tidak memuaskan, karena zat warna mempunyai sifat tahan terhadap degradasi biologi (recalcitrance). Proses penghilangan warna dari limbah cair industri tekstil juga dapat dilakukan secara kimiawi misalnya dengan penggunaan flokulan, koagulan, dan sedimentasi. Penghilangan warna secara kimia menggunakan koagulan akan menghasilkan lumpur (sludge) dalam jumlah yang relatif besar.

Salah satu metode kimia-fisika yang paling populer dan efektif untuk menghilangkan zat warna adalah adsorpsi. Terdapat berbagai bahan adsorben alami yang menarik, murah, serta dapat diperbaharui seperti mineral lempung (clay) dan kitosan yang memiliki kemampuan yang tinggi untuk mengadsorpsi berbagai jenis zat warna. Kitosan bersifat ramah lingkungan dan merupakan polisakarida tidak beracun. Sedangkan mineral lempung memiliki luas permukaan yang besar. Salah satu contoh mineral lempung adalah monmorillonit (MMT) yang memiliki luas permukaan yang besar dan kapasitas pertukaran kation yang tinggi. Monmorillonit bersifat hidrofobik, sehingga untuk digunakan sebagai adsorben monmorillonit harus dimodifikasi dengan menyisipkan senyawa lain ke dalam lapisan monmorillonit. Pada penelitian sebelumnya monmorillonit yang dimodifikasi dengan kitosan dapat digunakan untuk mengadsorpsi zat warna congo red dengan metode batch [2], zat warna Reactive Red 120 dengan metode batch [3], dan mengadsorpsi ion tembaga dengan metode fixed-bed column [4].

Dengan menggunakan metode fixed-bed column, waktu jenuh dari proses adsorpsi dapat ditentukan serta adsorben yang telah dipakai hingga jenuh dapat diregenerasi dengan lebih mudah. Oleh karena itu, pada penelitian ini akan digunakan kitosan sebagai senyawa yang digunakan dalam penyisipan monmorillonit untuk mengadsorpsi zat warna congo red dengan metode fixed-bed column. Sedangkan untuk menganalisis kemampuannya dalam mengadsorpsi zat warna congo red akan digunakan model kinetik Thomas.

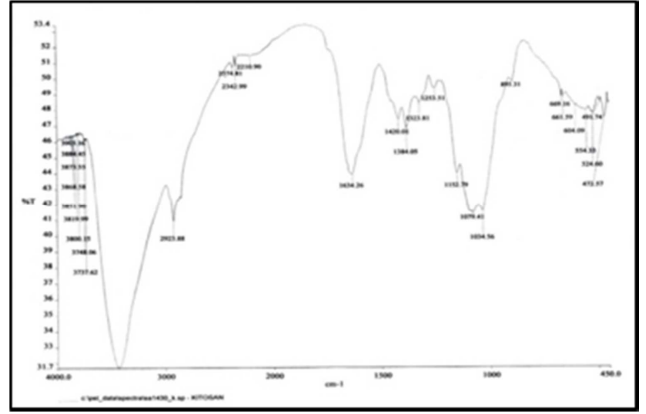

(1)

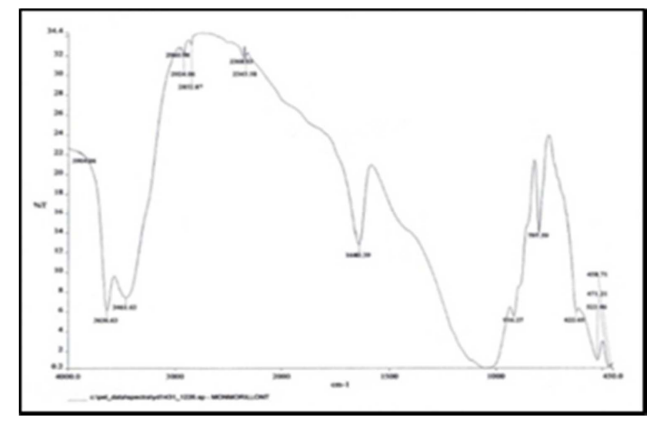

(2)

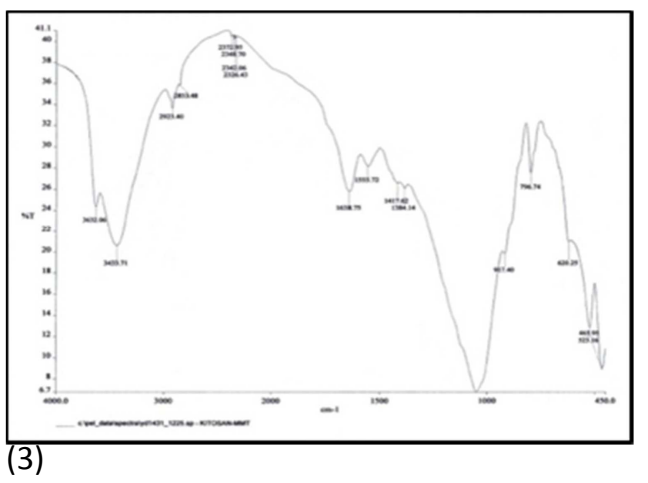

Gambar 1 Kurva Hasil Analisis FTIR; Kitosan (1), Monmorillonit (2), dan Kitosan-MMT (3). 


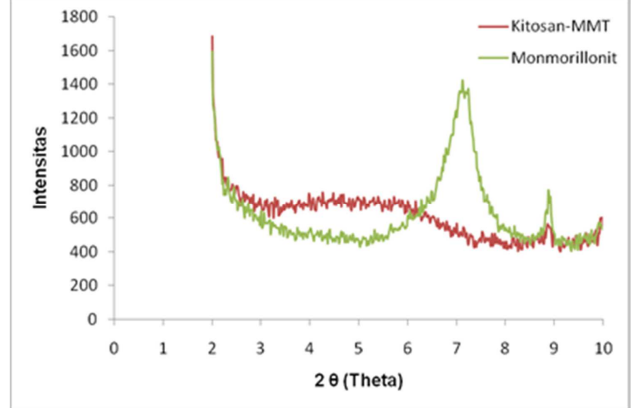

Gambar 2 Kurva Hasil Analisis XRD; Kurva Merah untuk Kitosan-MMT dan Kurva Hijau untuk Monmorillonit

\section{Metodologi Penelitian}

Alat-alat yang digunakan antara lain: alatalat gelas yang biasa digunakan di Laboratorium Kimia, hotplate magnetic stirrer, magnetic bar, $\mathrm{pH}$ meter, oven, set infus, kolom dengan tinggi $180 \mathrm{~mm}$ dan diameter 20 $\mathrm{mm}$, serta statif dan klem. Bahan-bahan yang digunakan antara lain: kitosan, monmorillonit, akuades, larutan asam asetat $1 \%$, larutan $\mathrm{HCl}$ $5 \%$, larutan $\mathrm{NAOH} 0,1 \mathrm{M}$, dan zat warna congo red. Untuk karakterisasi sampel digunakan instrument $X$-Ray Difraction (XRD), Fourier Transform Infra Red (FTIR), Surface Area Analyzer (SAA), dan Field Emission Scanning Electron Microscope (FESEM).

Tabel 1 Luas Permukaan Sampel Hasil Pengukuran dengan SAA

\begin{tabular}{cc}
\hline Sampel & $\begin{array}{c}\text { Luas Permukaan } \\
\left(\mathrm{m}^{2} / \mathrm{g}\right)\end{array}$ \\
\hline Kitosan & 1,313 \\
Kitosan-MMT & 12,882 \\
Monmorillonit & 21,995 \\
\hline
\end{tabular}

Kitosan-MMT yang digunakan sebagai adsorben dibuat sesuai dengan cara yang dilakukan oleh Li Wang [5], yaitu dengan cara mencampurkan 6 gram monmorillonit dengan $100 \mathrm{~mL}$ akuades. Kemudian suspensi diaduk selama enam jam pada kecepatan $300 \mathrm{rpm}$ dengan suhu $60^{\circ} \mathrm{C}$. Lalu mencampurkan 100 $\mathrm{mL}$ larutan kitosan 2\% ke dalam suspensi monmorillonit yang sedang diaduk sedikit demi sedikit. Suspensi yang telah siap kemudian dicuci dengan akuades dan dikeringkan dalam oven pada suhu $65^{\circ} \mathrm{C}$ selama 24 jam. Kemudian kitosan-MMT yang telah kering ditumbuk sampai halus dan diayak agar ukuran serbuk kitosan-MMT homogen. Serbuk yang dihasilkan kemudian dikarakterisasi dengan FTIR, XRD, SAA, dan FESEM.
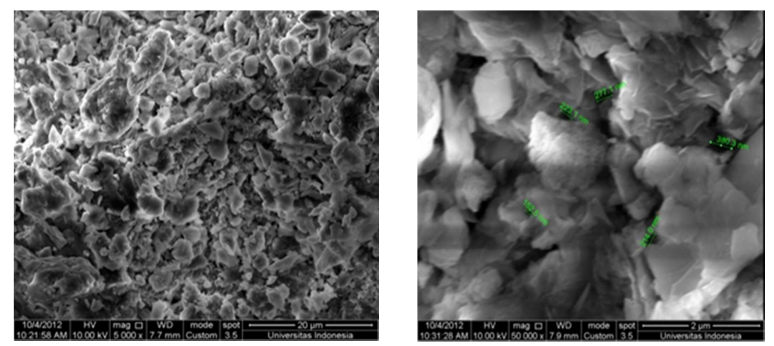

Gambar 3 Morfologi permukaan Berdasarkan Hasil Analisis FESEM; pada Perbesaran 5.000 kali (1) dan Perbesaran 100.000 kali (2).

Untuk pengoperasian adsorpsi, dilakukan adsorpsi untuk pengaruh berat adsorben dan laju alir adsorbat. Sebelum pengoperasian kolom adsorpsi, sampel zat warna congo red yang digunakan disesuaikan pada $\mathrm{pH}$ yang optimum, yaitu pada $\mathrm{pH} 6$ dengan konsentrasi 400 ppm. Hal ini berdasarkan penelitian sebelumnya dengan menggunakan metode batch yang menyatakan bahwa $\mathrm{pH}$ optimum pada sampel untuk adsorben kitosan-MMT adalah pada $\mathrm{pH} 6$.

Pengoperasian model kolom adsorpsi ini dengan cara mengalirkan sampel dari tabung sampel menuju kolom adsorpsi. Debit aliran sampel yang memasuki kolom diatur dengan menggunakan katup. Pengaturan pembukaan katup disesuaikan dengan kebutuhan debit air yang dikehendaki. Adapun variasi laju alir adsorbat yang digunakan adalah 0,$2 ; 0,4 ; 0,6$ $\mathrm{mL} /$ menit. Laju alir optimum ditentukan atas dasar nilai kapasitas adsorpsi yang terbesar.

Setelah diperoleh laju alir optimum adsorbat, kemudian dilakukan variasi terhadap berat adsorben untuk mengetahui berat adsorben optimum untuk mengadsorpsi zat 
warna congo red. Berat adsorben yang digunakan 0,3 dan 0,5 gram. Efluen diambil dan dianalisis setiap 30 menit pengoperasian kolom, dan dihentikan ketika kadar zat warna congo red efluen mencapai kadar congo red semula.

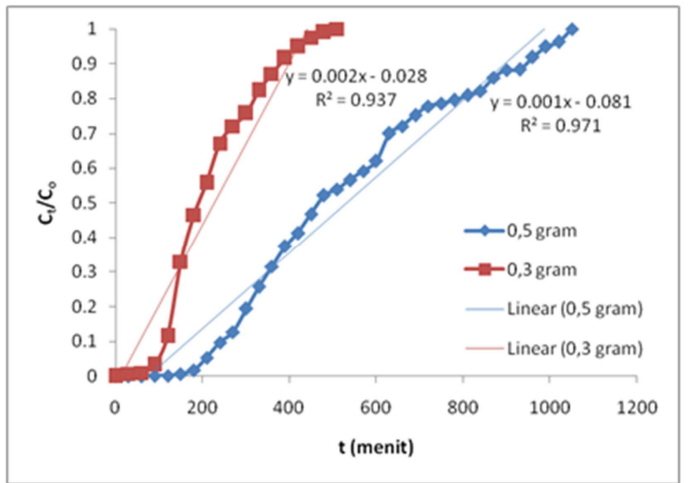

Gambar 4 Kurva Breakthrough untuk Variasi Berat Adsorben

\section{Hasil dan Pembahasan}

\subsection{Karakterisasi Kitosan-MMT}

Analisis FTIR dilakukan untuk ketiga sampel, yaitu kitosan, monmorillonit, dan kitosan-MMT. Berikut ini kurva analisis FTIR. Dari kurva tersebut, dapat dilihat kesamaan serapan antara kitosan dan monmorillonit dengan kitosan-MMT. Spektra kitosan-MMT memperlihatkan adanya serapan pada 3630 $\mathrm{cm}^{-1}-3433 \mathrm{~cm}^{-1}$ untuk regangan gugus $\mathrm{O}-\mathrm{H}$, serapan $2923 \mathrm{~cm}^{-1}$ menunjukkan vibrasi regangan ikatan $\mathrm{C}-\mathrm{H}$, vibrasi $\mathrm{C}=\mathrm{O}$ pada serapan $1638 \mathrm{~cm}^{-1}$, serapan $1555 \mathrm{~cm}^{-1}$ untuk vibrasi dari ikatan $\mathrm{N}-\mathrm{H}$, serapan $1048 \mathrm{~cm}^{-1}$ menunjukkan vibrasi ikatan Si-O, serapan 917 $\mathrm{cm}^{-1}$ untuk ikatan Al-O, dan serapan $796 \mathrm{~cm}^{-1}$ untuk ikatan $\mathrm{Mg}-\mathrm{OH}$. Puncak pada serapan $1648 \mathrm{~cm}^{-1}$ dari gugus $\mathrm{N}-\mathrm{H}$ pada kitosan yang terprotonasi $\left(\mathrm{NH}_{3}{ }^{+}\right)$bergeser ke $1555 \mathrm{~cm}^{-1}$ pada spektra kitosan-MMT. Hal ini dikarenakan gugus $\mathrm{N}-\mathrm{H}$ pada kitosan yang terprotonasi $\left(\mathrm{NH}_{3}{ }^{+}\right)$berikatan dengan $\mathrm{O}^{-}$dari monmorillonit. Hal ini menunjukkan bahwa kitosan telah berhasil diinterkalasikan ke dalam monmorillonit membentuk kitosan MMT yang memiliki karakteristik senyawa kitosan dan monmorillonit.
Untuk monmorillonit sampai derajat ke10 , puncak spesifik untuk monmorillonit ada di sekitar $7,08^{\circ}$. Pada puncak tersebut jarak basal (d-spacing) untuk monmorillonit adalah 12,46 $\AA$ atau 1,246 nm. Namun, puncak tersebut tidak terlihat untuk kitosan hasil interkalasi dengan monmorillonit, atau kitosan-MMT. Peak tertinggi untuk kitosan-MMT terlihat pada $5,18^{\circ}$ dengan $d$-spacing sebesar 17,04 Åatau $1,704 \mathrm{~nm}$. Hal ini menunjukkan bahwa kitosan telah terinterkalasi ke dalam monmorillonit. Terjadi pertukaran kation antara gugus amino dari kitosan dengan $\mathrm{Na}^{+}$ dari monmorillonit. Pergeseran peak dari $7,08^{\circ}$ menjadi $5,18^{\circ}$ untuk kitosan-MMT ini mengakibatkan $d$-spacing untuk kitosan-MMT juga bertambah. Pertambahan $d$-spacing menyatakan jarak lapis pada monmorillonit telah bertambah besar dengan adanya penyisip baru yang memiliki massa yang lebih besar.

Tabel 2 Nilai $q_{b}$ dan $q_{e}$ untuk Variasi Berat Adsorben

\begin{tabular}{ccccc}
\hline $\begin{array}{c}\text { Berat } \\
\text { adsorben } \\
\text { (gram) }\end{array}$ & $\begin{array}{c}\mathrm{V}_{\text {eff }} \\
(\mathrm{mL})\end{array}$ & $\begin{array}{c}\mathrm{t} \\
\text { (menit) }\end{array}$ & $\begin{array}{c}\mathrm{q}_{\mathrm{b}} \\
(\mathrm{mg} / \mathrm{g})\end{array}$ & $\begin{array}{c}\mathrm{q}_{\mathrm{e}} \\
(\mathrm{mg} / \mathrm{g})\end{array}$ \\
\hline 0,3 & 102 & 510 & 15,36 & 12,37 \\
0,5 & 210 & 1050 & 25,92 & 15,68 \\
\hline
\end{tabular}

Analisis yang ketiga adalah SAA untuk mengetahui luas permukaan dari kitosan, monmorillonit, dan kitosan-MMT. Data luas permukaan dari ketiganya ditunjukkan dalam tabel berikut. Dari tabel tersebut dapat diketahui bahwa kitosan murni memiliki luas permukaan terkecil dan monmorillonit memiliki luas permukaan terbesar. KitosanMMT sebagai adsorben diharapkan memiliki luas permukaan yang besar. Jika dibandingkan dengan kitosan murni, luas permukaan kitosan-MMT jauh lebih besar. Namun, luas permukaan kitosan-MMT ternyata lebih kecil dibandingkan dengan monmorillonit murni.

Dalam penelitian ini kitosan-MMT digunakan sebagai adsorben, dimana sifat 
mengadsorpnya dominan berasal dari kitosan. Namun, kitosan memiliki kekurangan dalam hal luas permukaan. Oleh karena itulah dilakukan pemodifikasian terhadap kitosan dengan monmorillonit untuk memperluas permukaan dari kitosan. Itu sebabnya luas permukaan kitosan-MMT tidak lebih besar dari monmorillonit murni, tapi lebih besar dari pada kitosan. Dengan penambahan monmorillonit ke dalam kitosan ternyata berhasil menambah luas permukaannya, sehingga adsorben memiliki kemampuan lebih baik untuk mengadsorp.

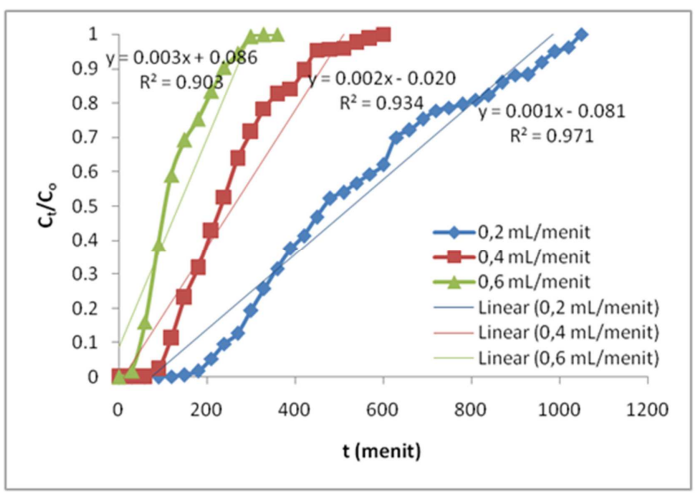

Gambar 5. Kurva Breakthrough untuk Variasi Laju Alir Adsorbat

Sedangkan dari hasil analisis FESEM dapat dilihat morfolgi permukaan dari kitosan-MMT dengan perbesaran hingga 100.000 kali. Dari kedua gambar tersebut dapat dilihat bahwa kitosan-MMT memiliki bentuk menyerupai bulat dengan ukuran yang tidak seragam (polidispersi) dan ukuran pori berkisar antara $152,5 \mathrm{~nm}$ sampai $380,3 \mathrm{~nm}$. Dengan adanya pori pada kitosan-MMT diharapkan akan menambah kemampuannya dalam menjerap congo red.

\subsection{Analisis Kurva Breakthrough}

Dalam penelitian ini telah dilakukan dua variabel yang dapat mempengaruhi proses adsorpsi, yaitu pengaruh berat adsorben dan pengaruh laju alir adsorbat. Pada pengaruh berat adsorben ini digunakan dua variasi berat, yaitu 0,3 gram dan 0,5 gram. Pada
Tabel 3 Nilai $q_{b}$ dan $q_{e}$ untuk Variasi Laju Alir Adsorbat

\begin{tabular}{ccccc}
\hline $\begin{array}{c}\text { Laju alir } \\
(\mathrm{mL} / \text { menit })\end{array}$ & $\begin{array}{c}\mathrm{V}_{\text {eff }} \\
(\mathrm{mL})\end{array}$ & $\begin{array}{c}\mathrm{t} \\
\text { (menit) }\end{array}$ & $\begin{array}{c}\mathrm{q}_{\mathrm{b}} \\
(\mathrm{mg} / \mathrm{g})\end{array}$ & $\begin{array}{c}\mathrm{q}_{\mathrm{e}} \\
(\mathrm{mg} / \mathrm{g})\end{array}$ \\
\hline 0,2 & 210 & 1050 & 25,92 & 15,68 \\
0,4 & 240 & 600 & 17,28 & 14,72 \\
0,6 & 360 & 360 & 2,016 & 13,04 \\
\hline
\end{tabular}

kondisi tersebut konsentrasi zat warna congo red yang digunakan adalah 400ppm dengan laju alir 0,0002 L/menit. Untuk berat adsorben 0,3 gram pengaliran zat warna congo red dihentikan pada menit ke-510. Sedangkan untuk berat adsorben 0,5 gram pengaliran dihentikan pada menit ke-1050. Data yang diperoleh saat proses adsorpsi disajikan dalam bentuk kurva breakthrough. Berikut ini adalah kurva breakthrough untuk berat adsorben 0,3 gram dan 0,5 gram.

Berdasarkan kurva tersebut, dapat dihitung kapasitas adsorpsi pada saat breakthrough $\left(\mathrm{q}_{\mathrm{b}}\right)$ dan saat exhaustion $\left(\mathrm{q}_{\mathrm{e}}\right)$, yaitu ketika konsentrasi efluen mencapai $10 \%$ dan $90 \%$ dari konsentrasi influen. Berikut adalah tabel nilai $q_{b}$ dan $q_{e}$ yang didapat berdasarkan kurva breakthrough.

Tabel 4 Nilai $k_{\text {Th }}$ dan $q_{o}$ untuk Pengaruh Berat Adsorben

\begin{tabular}{ccc}
\hline $\begin{array}{c}\text { Berat } \\
\text { adsorben } \\
\text { (gram) }\end{array}$ & $\begin{array}{c}\mathrm{k}_{\mathrm{TH}} \\
(\mathrm{L} / \mathrm{menit} . \\
\mathrm{g})\end{array}$ & $\mathrm{q}_{\mathrm{o}}(\mathrm{mg} / \mathrm{g})$ \\
\hline 0,3 & 0,0000475 & 65,3614 \\
0,5 & 0,00002 & 99,62 \\
\hline
\end{tabular}

Tabel 5. Nilai $\mathrm{k}_{\text {Th }}$ dan $\mathrm{q}_{\mathrm{o}}$ untuk Pengaruh Laju Alir Adsorbat

\begin{tabular}{ccc}
\hline $\begin{array}{c}\text { Laju alir } \\
(\mathrm{L} / \text { menit })\end{array}$ & $\begin{array}{c}\mathrm{k}_{\mathrm{TH}}(\mathrm{L} / \mathrm{menit} \\
\cdot \mathrm{g})\end{array}$ & $\mathrm{q}_{\mathrm{o}}(\mathrm{mg} / \mathrm{g})$ \\
\hline 0,0002 & 0,00002 & 99,62 \\
0,0004 & 0,0000425 & 90,73 \\
0,0006 & 0,00007 & 65,59 \\
\hline
\end{tabular}

Sesuai dengan tabel di atas, semakin banyak adsorben yang digunakan berarti 
semakin banyak pula jumlah zat warna congo red yang dapat diserap serta semakin lama waktu yang dibutuhkan adsorben untuk mengadsorpsi adsorbat sampai keadaan jenuh. Begitu pula dengan kapasitas adsorpsi pada kondisi breakthrough dan exhaustion, nilai $\mathrm{q}_{\mathrm{b}}$ dan $\mathrm{q}_{\mathrm{e}}$ meningkat sesuai dengan meningkatnya berat adsorben. Berarti pada berat adsorben 0,5 gram mengindikasikan lebih banyak bagian aktif yang mengikat adsorbat dengan lebih baik yang dapat dilihat dari nilai kapasitas adsorpsinya yang lebih besar. Sedangkan pada berat adsorben 0,3 gram dan dengan laju alir yang sama membuat congo red tidak cukup memiliki waktu untuk menyebar ke dalam sela-sela adsorben dengan baik, sehinga nilai $\mathrm{q}_{\mathrm{b}}$ dan $\mathrm{q}_{\mathrm{e}}$-nya lebih kecil. Dari kurva breakthrough pun dapat dilihat bentuk kurva untuk berat adsorben 0,3 gram lebih curam dari pada berat adsorben 0,5 gram yang berarti waktu untuk mencapai kondisi breakthrough lebih cepat tercapai. Dari data tersebut dapat disimpulkan bahwa berat adsoben 0,5 gram memiliki kemampuan mendistribusikan congo red dengan lebih baik sehingga proses adsorpsi pun dapat lebih maksimal.

Pada pengaruh laju alir adsorbat digunakan tiga variasi laju alir, yaitu 0,2 $\mathrm{mL} /$ menit, 0,4 $\mathrm{mL} /$ menit, dan 0,6 $\mathrm{mL} /$ menit. Pada kondisi tersebut konsentrasi zat warna congo red yang digunakan adalah 400ppm dengan berat adsorben sebesar 0,5 gram. Untuk laju alir 0,2 $\mathrm{mL} /$ menit pengaliran zat warna congo red dihentikan pada menit ke1050. Sedangkan untuk laju alir $0,4 \mathrm{~mL} /$ menit pengaliran dihentikan pada menit ke-600. Dan untuk laju alir $0,6 \mathrm{~mL} / \mathrm{menit}$ pengaliran dihentikan pada menit ke-360, yaitu pada saat konsentrasi efluen sama dengan konsentrasi influen.

Hasil data yang diperoleh dari proses adsorpsi juga disajikan dalam kurva breakthrough. Berikut adalah kurva breakthrough untuk pengaruh laju alir adsorbat. Berdasarkan kurva tersebut, dapat dihitung kapasitas adsorpsi pada saat breakthrough $\left(\mathrm{q}_{\mathrm{b}}\right)$ dan saat exhaustion $\left(\mathrm{q}_{\mathrm{e}}\right)$, yaitu ketika konsentrasi efluen mencapai $10 \%$ dan $90 \%$ dari konsentrasi influen. Berikut adalah tabel nilai $\mathrm{q}_{\mathrm{b}}$ dan $\mathrm{q}_{\mathrm{e}}$ yang didapat berdasarkan kurva breakthrough.

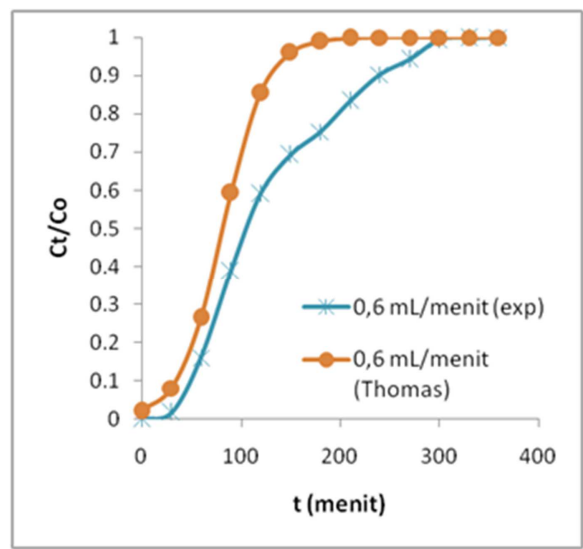

(a)

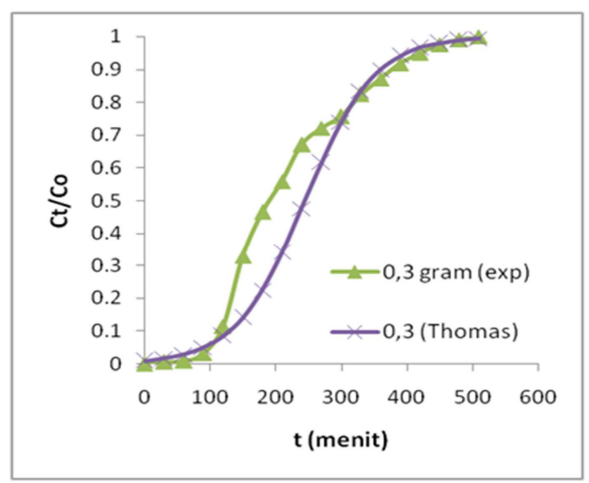

(b)

Gambar 6 Kurva Breakthrough Berdasarkan Model Adsorpsi Thomas dan Percobaan pada Laju Alir 0,6 $\mathrm{mL} /$ menit dengan Berat 0,5 Gram (a) dan pada Laju

Alir 0,2 mL /menit dengan Berat 0,2 Gram.

Dari kurva breakthrough terlihat bahwa bentuk kurva semakin curam seiring dengan semakin besarnya laju alir. Hal ini disebabkan karena waktu untuk tercapainya kondisi breakthrough dan exhaustion lebih cepat tercapai. Pada tabel 4 juga dinyatakan waktu adsorpsi yang dibutuhkan untuk mencapai keadaan jenuh semakin berkurang seiring dengan bertambah cepatnya laju alir. Laju alir juga menunjukkan seberapa lamanya waktu kontak adsorben dengan adsorbat. Semakin cepat laju alirnya berarti semakin cepat juga 
waktu berinteraksinya antara adsorben dengan adsorbat. Inilah yang menyebabkan nilai $q_{b}$ dan $q_{e}$ semakin menurun dengan bertambah cepatnya laju alir. Pada laju alir tertinggi, congo red mengalir dengan lebih cepat sehingga distribusinya ke sela-sela pori adsorben kurang maksimal. Akibatnya efluen keluar dari kolom sebelum kesetimbangan terjadi [6].

Dari data-data tersebut dapat disimpulkan bahwa laju alir 0,2 $\mathrm{mL} /$ menit memiliki kemampuan adsorpsi yang lebih baik dibandingkan laju alir $0,4 \mathrm{~mL} / \mathrm{menit}$ dan 0,6 $\mathrm{mL} /$ menit. Hal ini disebabkan pada laju alir 0,2 $\mathrm{mL} /$ menit congo red memiliki waktu kontak lebih lama dengan adsorben sehingga pendistribusian dan keseimbangan di setiap sela adsorben dapat terjangkau lebih baik.

\subsection{Model Kinetika Adsorpsi Thomas}

Model kinetika Thomas adalah salah satu model kinetika yang dikembangkan untuk mengkaji proses adsorpsi heterogen dalam sistem yang mengalir [7]. Model kinetika Thomas dinyatakan dengan persamaan:

$$
\frac{C_{t}}{C_{o}}=\frac{1}{1+\exp \left[\frac{k_{T h}}{Q}\left(q_{o} w-C_{o} V_{e f}\right)\right]}
$$

Dimana $C_{t}$ adalah konsentrasi efluen yang keluar dari kolom $(\mathrm{mg} / \mathrm{L})$ pada waktu $\mathrm{t}, \mathrm{C}_{\mathrm{o}}$ adalah konsentrasi awal sebelum masuk kolom (mg/L), $\mathrm{Q}$ adalah laju alir volumetrik (L/menit), w adalah massa adsorben dalam kolom (g), $k_{\text {Th }}$ adalah tetapan laju Thomas (L/menit.g), qo adalah kapasitas adsorpsi total adsorben dalam kolom $(\mathrm{mg} / \mathrm{g})$, dan $\mathrm{V}_{\text {ef }}$ adalah volume efluen yang keluar dari kolom (L) pada waktu t. Persamaan tersebut dapat diubah menjadi bentuk linear, seperti yang dinyatakan pada persamaan:

$$
\ln \left(\frac{C_{o}}{C_{t}}-1\right)=\frac{k_{T h} q_{o} w}{Q}-k_{T h} C_{o} t
$$

Model Thomas dapat diubah menjadi bentuk persamaan linear seperti pada persamaan di atas sehingga dapat digunakan untuk mengolah data kurva breakthrough menggunakan cara regresi linear yang sederhana, dimana $\ln \left(C_{0} / C_{t}-1\right)$ sebagai ordinat atau sumbu $y$ dan $t$ sebagai absis atau sumbu $x$. Koefisien regresi linear $r^{2}$ harus berada pada interval 0,9-1,0. Dari regresi linear akan diperoleh persamaan linear $y=a+$ $\mathrm{bx}$, dimana a adalah intercept dan $\mathrm{b}$ adalah gradient. Berdasarkan nilai intercept a dapat dihitung kapasitas adsorpsi qo dan dari nilai gradient dapat dihitung tetapan laju Thomas $\mathrm{k}_{\mathrm{Th}}$. Berikut ini tabel yang menyatakan nilai $\mathrm{k}_{\mathrm{Th}}$ dan $\mathrm{q}_{\mathrm{o}}$.

Terlihat dari kedua tabel di atas, nilai $\mathrm{k}_{\mathrm{Th}}$ berbanding terbalik dengan $q_{0}$. Semakin besar nilai $k_{T h}$ maka semakin kecil nilai $q_{0}$. Untuk pengaruh berat adsorben, kenaikan jumlah adsorben sebanding dengan peningkatan nilai $q_{0}$. Namun pada pengaruh laju alir, semakin cepat laju alirnya nilai $\mathrm{q}_{\mathrm{o}}$-nya semakin kecil. Tabel 5 dan 6 menunjukkan berat adsorben 0,5 gram dengan laju alir $0,2 \mathrm{~mL} /$ menit memiliki nilai qo terbesar, yaitu 99,62 mg/g.

Dari persamaan kurva tersebut, hanya ada dua adsorpsi yang memenuhi kriteria dari model adsorpsi Thomas, yaitu pada laju alir $0,6 \mathrm{~mL} /$ menit dengan berat adsorben 0,5 gram dan pada laju alir $0,2 \mathrm{~mL} / \mathrm{menit}$ dengan berat adsorben 0,3 gram. Nilai $\mathrm{k}_{\mathrm{Th}}$ dan $\mathrm{q}_{\mathrm{o}}$ yang telah didapat, digunakan untuk membuat kurva breakthrough prediksi berdasarkan teori adsorpsi Thomas. Berikut ini adalah kurva breaktrough hasil percobaan dan berdasarkan hasil perhitungan dari model adsorpsi Thomas.

\section{Kesimpulan}

Berdasarkan hasil penelitian dan pembahasan, diperoleh kesimpulan bahwa kitosan-MMT yang berhasil dibuat memiliki karakter khusus yang mengindikasikan adanya serapan dari $\mathrm{Si}-\mathrm{O}, \mathrm{Al}-\mathrm{O}$, dan amina dari monmorillonit dan kitosan. Serta adanya peningkatan jarak basal dari $12,46 \AA$ menjadi $17,04 \AA$ dan dengan luas permukaan 12,882 
$\mathrm{m}^{2} / \mathrm{g}$. Untuk adsorpsi pengaruh berat adsorben didapatkan bahwa semakin bertambahnya berat adsorben waktu adsorpsi, volume adsorbat, dan nilai $\mathrm{q}_{\mathrm{b}}$ dan $\mathrm{q}_{\mathrm{e}}$ yang didapatkan juga semakin besar. Adsorpsi optimal terjadi pada berat adsorben sebesar 0,5 gram pada laju alir $0,2 \mathrm{~mL} /$ menit dan konsentrasi congo red 400ppm gram dengan $\mathrm{q}_{\mathrm{b}}$ dan $\mathrm{q}_{\mathrm{e}}$ masing-masing sebesar $25,92 \mathrm{mg} / \mathrm{g}$ dan 15,68 mg/g. Sedangkan untuk adsorpsi pengaruh laju alir adsorbat didapatkan bahwa semakin bertambahnya laju alir adsorbat waktu adsorpsi, volume adsorbat, dan nilai $\mathrm{q}_{\mathrm{b}}$ dan $\mathrm{q}_{\mathrm{e}}$ yang akan semakin kecil. Adsorpsi optimal terjadi pada laju alir adsorbat sebesar $0,2 \mathrm{~mL} /$ menit pada berat adsorben 0,5 gram dan konsentrasi congo red 400ppm gram dengan $\mathrm{q}_{\mathrm{b}}$ dan $\mathrm{q}_{\mathrm{e}}$ masing-masing sebesar $25,92 \mathrm{mg} / \mathrm{g}$ dan 15,68 mg/g. Model adsorpsi Thomas sesuai untuk kondisi berat adsorben 0,3 gram dengan laju alir $0,2 \mathrm{~mL} /$ menit dan kondisi laju alir $0,6 \mathrm{~mL} / \mathrm{menit}$ dengan berat adsorben 0,5 gram.

\section{Ucapan Terima Kasih}

Penulis mengucapkan terima kasih kepada Ibu Erdawati dan Bapak Imam Santoso yang telah membimbing dan membantu baik secara moril ataupun materil selama penelitian dan penyusunan skripsi. Juga kepada teman-teman Chems'08 khususnya Sakti Wicaksana, serta seluruh pihak yang telah membantu selama penelitian dan penyelesaian skripsi.

\section{Daftar Pustaka}

[1] Muruganandham, M. dan M. Swaminathan. 2004. Solar Photocatalytic Degradation of a Reactive Azo Dye in $\mathrm{TiO}_{2}$-Suspension. Solar Energy Materials and Solar Cells. 81: 439-457.

[2] Wang, Li dan Aiqin Wang. 2007. Adsorpstion Characteristics of Congo Red Onto the Chitosan/Montmorillonite Nanocomposites. Journal of Hazardous Materials. 147: 979-985.

[3] Kittinaovarat, Siriwan dan Panida Kansomwan. 2010. Chitosan/Modified Montmorillonite Beads and Adsorption Reactive Red 120. Applied Clay Science. 48: 87-91.

[4] Futalan, Cybelle Morales dan Chi-Chuan Kan. 2010. Fixed-bed Column Studies on the Removal of Copper Using Chitosan Immobilized on Bentonite. Carbohydrate Polymer. 83: 697-704.

[5] Wang, Li dan Aiqin Wang. 2005. Biopolymer Chitosan/Montmorillonite Nanocomposites: Preparation and Characterization. Polymer Degradation and Stability. 90: 123-131.

[6] Vijayaraghavan, K., Jegan, J., Palanivelu, K., \& Velan, M. 2004. Removal of Nickel (II) lons from Aqueous Solution Using Crab Shell Particles In A Packed Bed Up-Flow Column. Journal of Hazardous Materials. B113: 223-230.

[7] Thomas, H.C., 1944. Heterogeneous Ion Exchange In A Flowing System. J. Am. Chem. Soc. 66: 1664-1666. 